\title{
Geologic Map of the Fittstown 7.5' Quadrangle, Pontotoc and Johnston Counties, Oklahoma
}
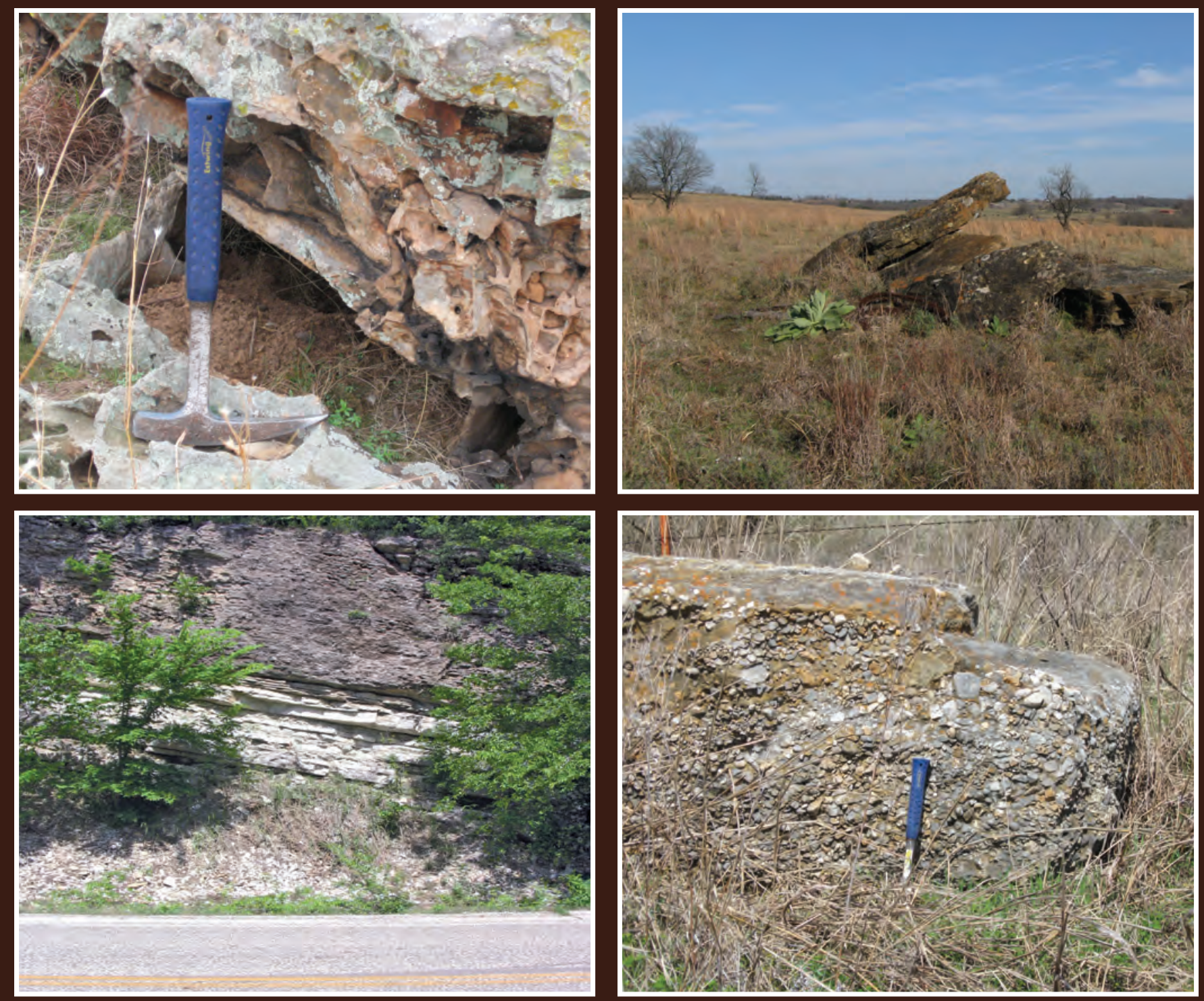

Pamphlet to accompany

Scientific Investigations Map 3371 
Cover. Upper left, Solution cavities and box work breccia in fine-grained sandstone of West Spring Creek Formation (Arbuckle Group) in the central part of the map area. Sandstone beds occur but are uncommon within this formation in the map area. Upper right, Exposure of Hart limestone (informal) of the Desmoinesian Boggy Formation about 10 miles northeast of the map area in the region of the Lawrence uplift. Lower right, Limestone conglomerate that is common in Desmoinesian rocks in the northeast part of the map area. [Also shown as figure 9 in the pamphlet.] Lower left, Contact of dark-weathering, wavy-bedded limestone of the Viola Group overlying white-weathering, tabular-bedded, micritic limestone of the Bromide Formation (Simpson Group) along Highway 377 near the central part of the eastern map border. 


\section{Geologic Map of the Fittstown 7.5' Quadrangle, Pontotoc and Johnston Counties, Oklahoma}

By David J. Lidke and Charles D. Blome

Pamphlet to accompany

Scientific Investigations Map 3371 


\section{U.S. Department of the Interior SALLY JEWELL, Secretary}

\section{U.S. Geological Survey Suzette M. Kimball, Director}

\section{U.S. Geological Survey, Reston, Virginia: 2017}

For more information on the USGS - the Federal source for science about the Earth, its natural and living resources, natural hazards, and the environment—visit http://www.usgs.gov or call 1-888-ASK-USGS.

For an overview of USGS information products, including maps, imagery, and publications, visit http://store.usgs.gov.

Any use of trade, firm, or product names is for descriptive purposes only and does not imply endorsement by the U.S. Government.

Although this information product, for the most part, is in the public domain, it also may contain copyrighted materials as noted in the text. Permission to reproduce copyrighted items must be secured from the copyright owner.

Suggested citation:

Lidke, D.J., and Blome, C.D., 2017, Geologic map of the Fittstown 7.5' quadrangle, Pontotoc and Johnston Counties, Oklahoma: U.S. Geological Survey Scientific Investigations Map 3371, 14 p., 1 sheet, scale 1:24,000, https://doi.org/10.3133/sim3371.

ScienceBase citation:

Lidke, D.J., and Blome, C.D., 2016, Data release for Geologic Map of the Fittstown 7.5' quadrangle, Pontotoc and Johnston Counties, Oklahoma: U.S. Geological Survey data release, https://doi.org/10.5066/F77P8WJN.

ISBN 2329-132X (online) 


\section{Contents}

Abstract
Introduction
Previous Geologic Mapping
Geologic Mapping of the Fittstown Ouadrangle
Geologic Setting
$\quad$ Stratigraphy
$\quad$ Regional Structure
Structural Features in the Fittstown Quadrangle
Description of Map Units
Ouaternary Stratigraphy
Paleozoic Stratigraphy
References Cited.

\section{Figures}

1. Map showing location of Fittstown $7.5^{\prime}$ quadrangle, Pontotoc and Johnston Counties, Oklahoma, including the approximate outline of the Arbuckle Mountains.......1

2. Photographs showing $A$, relatively flat, highland landscape that characterizes all but the northeastern part of the map area. $B$, Small hills and valleys in northeastern part of map area, which characterize the northeastern flank of the highland shown in $A$......

3. Photograph showing typical road exposure of West Spring Creek Formation in northeast part of map area

4. Generalized geologic sketch map and cross section of the northeastern Arbuckle Mountains, Oklahoma, including outline of the Fittstown $7.5^{\prime}$ quadrangle map area .......4

5-9. Photographs showing:

5. A, Greenish-gray, fine-grained to micritic dolomite of the West Spring Creek Formation showing laminations that are common in this rock unit. $B$, Light-tan to pale-green, tabular, thin bedded and laminated dolomite of the West Spring Creek Formation (Arbuckle Group) about 1.5 mi east of south-central part of eastern map border.

6. A, "Birdseye" limestone of the McLish Formation (Simpson Group) showing irregular flecks and masses of clear calcite in white to light-gray micritic limestone. $B$, Blocky-bedded "birdseye" limestone in quarry wall near central part of eastern map border.

7. A, Solution cavity in the undifferentiated map unit consisting of the Bromide and McLish Formations (Obm) about 1 mi east of southern part of eastern map border. $B$, Solution cavities (vugs) in basal sandstone member of Oil Creek Formation (Simpson Group) about 1 mi east of south-central part of eastern map border

8. Highly fractured West Spring Creek Formation along quarry wall in east-central

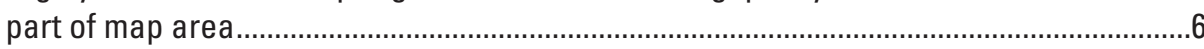

9. Limestone conglomerate that is common in Desmoinesian rocks in the northeast part of the map area 


\section{Conversion Factors}

Inch to SI

\begin{tabular}{ccl}
\hline \multicolumn{1}{c}{ Multiply } & By & \multicolumn{1}{c}{ To obtain } \\
\hline & Length & \\
\hline inch (in.) & 2.54 & centimeter (cm) \\
inch (in.) & 25.4 & millimeter (mm) \\
foot (ft) & 0.3048 & meter (m) \\
mile (mi) & 1.609 & kilometer (km) \\
\hline \multirow{2}{*}{ SI to Inch } & & \\
\hline & By & To obtain \\
\hline & Length & \\
\hline & 0.3937 & inch (in.) \\
\hline centimeter $(\mathrm{cm})$ & 3.281 & foot (ft) \\
meter $(\mathrm{m})$ & 0.6214 & mile (mi) \\
\hline
\end{tabular}




\title{
Geologic Map of the Fittstown 7.5' Quadrangle, Pontotoc and Johnston Counties, Oklahoma
}

\author{
By David J. Lidke and Charles D. Blome
}

\section{Abstract}

This 1:24,000-scale geologic map includes new geologic mapping as well as compilation and revision of previous geologic maps in the area. Field investigations were carried out during 2009-2011 that included mapping and investigations of the geology and hydrology of the Chickasaw National Recreation Area, Oklahoma, southwest of the map area.

The Fittstown quadrangle is in Pontotoc and Johnston Counties in south-central Oklahoma, which is in the northeastern part of the Arbuckle Mountains. The Arbuckle Mountains are composed of a thick sequence of Paleozoic sedimentary rocks that overlie Lower Cambrian and Proterozoic igneous rocks; these latter rocks are not exposed in the quadrangle. During the Middle to Late Pennsylvanian, the Arbuckle Mountains region was folded, faulted, and uplifted. Periods of erosion followed these Pennsylvanian mountain-building events, beveling this region and ultimately developing the current subtle topography that includes hills and incised uplands. The southern and northwestern parts of the Fittstown quadrangle are directly underlain by Lower Ordovician dolomite of the Arbuckle Group that has eroded to form an extensive, stream-incised upland containing the broad, gently southeast-plunging, Pennsylvanian-age Hunton anticline. The northeastern part of the map area is underlain by Middle Ordovician to Pennsylvanian limestone, shale, and sandstone units that predominantly dip northeast and form the northeastern limb of the Hunton anticline; this limb is cut by steeply dipping, northwest-southeast striking faults of the Franks fault zone. This limb and the Franks fault zone define the southwestern margin of the Franks graben, which is underlain by Pennsylvanian rocks in the northeast part of the map area.

\section{Introduction}

The Fittstown $7.5^{\prime}$ quadrangle is located in south-central Oklahoma, in Pontotoc and Johnston Counties, about 80 miles (mi) (130 kilometers [km]) south-southeast of Oklahoma City, in the northeastern part of the Arbuckle Mountains (fig. 1). Geologic mapping of the Fittstown quadrangle was completed as part of a much larger geologic framework study of the Arbuckle-Simpson aquifer (Christenson and others, 2011; Blome and others, 2013).
The original 1:72,000-scale geologic map of the Arbuckle Mountains (Ham and others, 1954) includes and extends over the Fittstown quadrangle; this map and a later revised version of it at 1:100,000-scale (Johnson, 1990), provided useful source map information during our larger scale (1:24,000 scale) mapping of the Fittstown quadrangle. The 1990 map supersedes the original 1954 map that is no longer available except in map collections at some libraries. We obtained the original 1954 map from the U.S. Geological Survey (USGS) library and in many areas we found the larger scale of this map to be useful during our mapping investigations.

The Arbuckle Mountains are a deeply eroded, ancient mountain range with little topographic relief. Late Paleozoic (Middle-Late Pennsylvanian) deformation and uplift of a thick sequence of Paleozoic sedimentary rocks and underlying Lower Cambrian and Proterozoic igneous rocks formed the Arbuckle Mountains. Subsequent erosion beveled the ancient Arbuckle Mountains to the low topographic relief present today. The northeastern part of the Arbuckle Mountains, which includes the Fittstown quadrangle, is currently a broad, stream-incised highland that has a topographically prominent northeastern flank, which separates it from lowlands to the northeast (fig. $2 A$ and $B$ ). These principal topographic features coincide with major structural features that control the exposed distribution of rock units in the northeastern Arbuckle Mountains and in the map area. The Fittstown quadrangle includes parts of the plateau-like highland, its northeastern flank, and the lowlands to northeast.

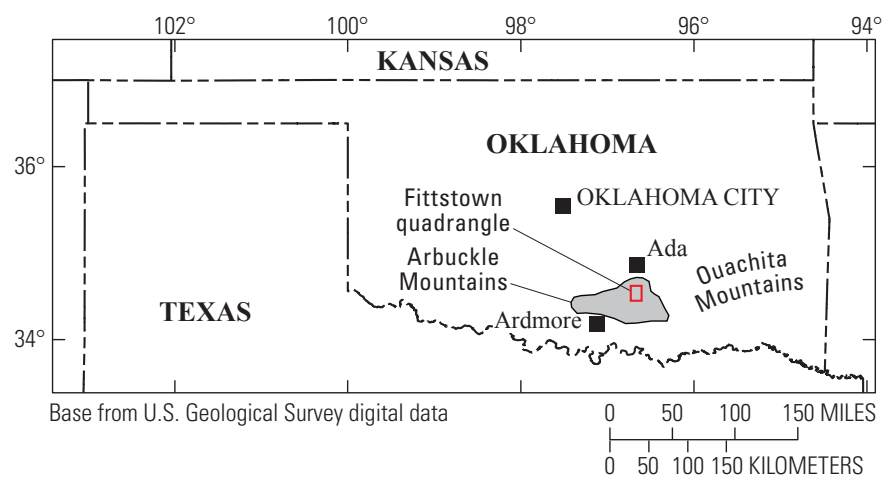

Figure 1. Location of Fittstown 7.5' quadrangle, Pontotoc and Johnston Counties, Oklahoma, including the approximate outline of the Arbuckle Mountains. 


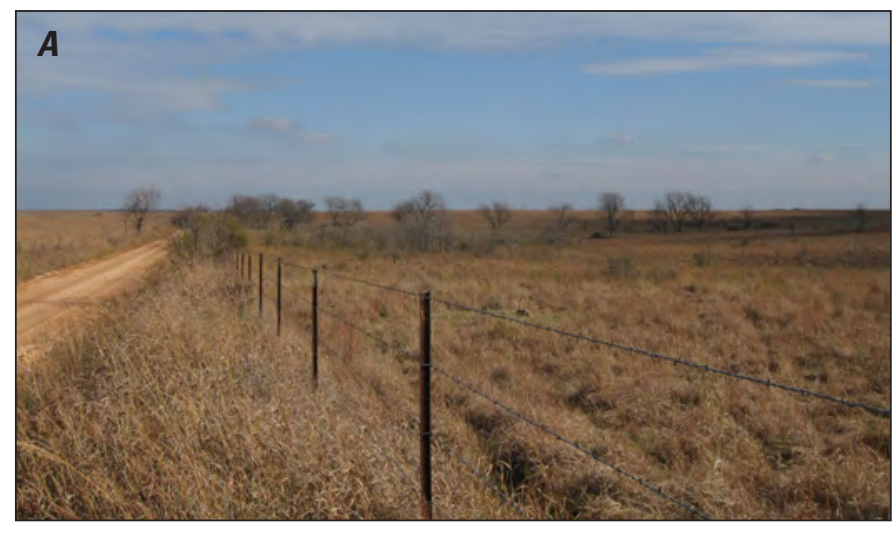

B

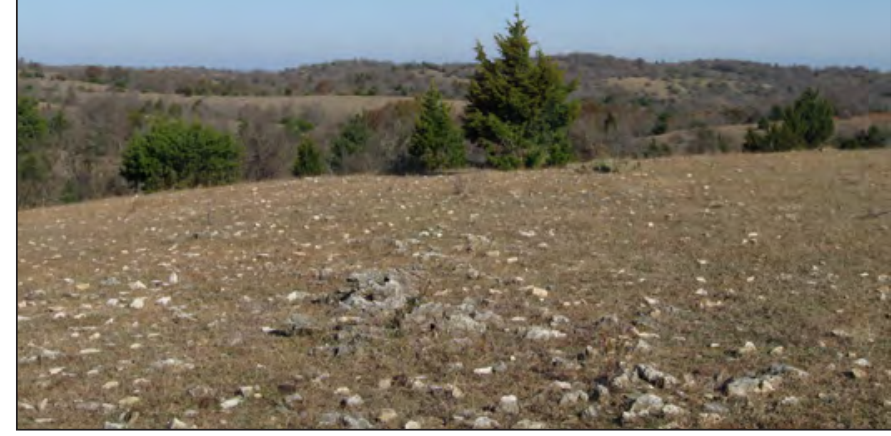

Figure 2. A, Relatively flat, highland landscape that characterizes all but the northeastern part of the map area. View is looking east from near the western border of the map area. $B$, Small hills and valleys in northeastern part of map area, which characterize the northeastern flank of the highland shown in $A$. View is looking north-northeast from the highland. Over the horizon, the northeast flank descends abruptly into the lowland that characterizes the Franks graben area and northeast corner of the map area.

\section{Previous Geologic Mapping}

Taff $(1903,1904)$ produced the first geologic maps of the Arbuckle Mountains at a 1:125,000 scale. The lithostratigraphic nomenclature in these early maps included many of the same, or similar rock-unit names as used today. Units included on these two maps were their "Reagan sandstone" (lowermost formation of the Timbered Hills Group today, that is exposed to the south of the mapped area), "Arbuckle limestone" (now elevated to the Arbuckle Group), "Simpson formation" (now the Simpson Group), and the "Viola limestone" (now the Viola Group).

Geologic investigations and mapping of the Arbuckle Mountains surged in the 1940s and 1950s and resulted in the1:72,000-scale geologic map of the Arbuckle Mountains by Ham and others (1954). This map was later included in an Oklahoma Geological Survey guidebook by Ham (1955). Johnson (1990) later revised the Ham and others (1954) geologic map as Johnson (1990), which was included by Fairchild and others (1990) in an Oklahoma Geological Survey Circular on the hydrology of the Arbuckle Mountains.
The first digital map coverage of the Arbuckle Mountains, which included the area of the Fittstown quadrangle, was the geospatial map database constructed by Cederstrand (1996). This map was digitized from the 1:250,000-scale Hydrologic Atlas map 3 of Hart (1974). The small scale of Cederstrand's (1996) digital map and its source map (Hart, 1974) and the fact that they don't include attitudes (strikes and dips) or Quaternary deposits, limited their use in our Fittstown quadrangle map compilation. The digital geologic map databases of Heran (2003) and Stoeser (2007) included a geodatabase of the central United States (including Oklahoma), but are at 1:500,000-scale and therefore also of too small a scale to help in constructing a large-scale geologic map of the Fittstown quadrangle. We scanned and registered the smaller scale geologic maps of Ham and others (1954) and Johnson (1990) that are 1:72,000- and 1:100,000-scale, respectively, as they proved useful in our mapping and compilation.

The only other published geologic maps in the Arbuckle Mountain region are geologic maps of the Stonewall quadrangle (Morgan, 1924) and of the Chickasaw National Recreation Area (CNRA; Blome and others, 2013). The 1924 map of the Stonewall quadrangle covers the Fittstown quadrangle and much of the northeastern part of the Arbuckle Mountains; its small scale (1:125,000-scale), lack of a topographic base map (planimetric base map), and the availability of more recent smaller scale maps that cover the Stonewall quadrangle region (Ham and others, 1954; Johnson, 1990) made it of little use in our compilation of the Fittstown quadrangle. The CNRA map covers part of the north-central Arbuckle Mountains, about $23 \mathrm{mi}(37 \mathrm{~km})$ southwest of the map area; like the Fittstown quadrangle, it is a 1:24,000-scale map.

\section{Geologic Mapping of the Fittstown Quadrangle}

The geologic map includes both new mapping, and in places, modifications or adjustments to the previous, smallerscale geologic maps (for example, Ham and others, 1954; Johnson, 1990). The Fittstown quadrangle and much of the surrounding region, is one of dominantly subdued topography and relatively thick vegetation that includes trees, bushes, and grasses. Rock exposures are limited throughout much of the map area and in many areas only float or rubble eroded from near-surface bedrock are present. Throughout much of the quadrangle, however, Quaternary deposits are lacking, soil development is very thin, and the graded surface of many unpaved roads exposes weathered bedrock (fig. 3).

All land within and adjacent to the Fittstown quadrangle is privately owned and nearly all variably sized land parcels are fenced, limiting mapping access without permissions. Public roads between fenced land parcels transect much of the quadrangle and provide minimal access to most parts of the map area. In areas of poor access, particularly in the southern part of the quadrangle, we relied on the previous geologic maps and aerial photography. 


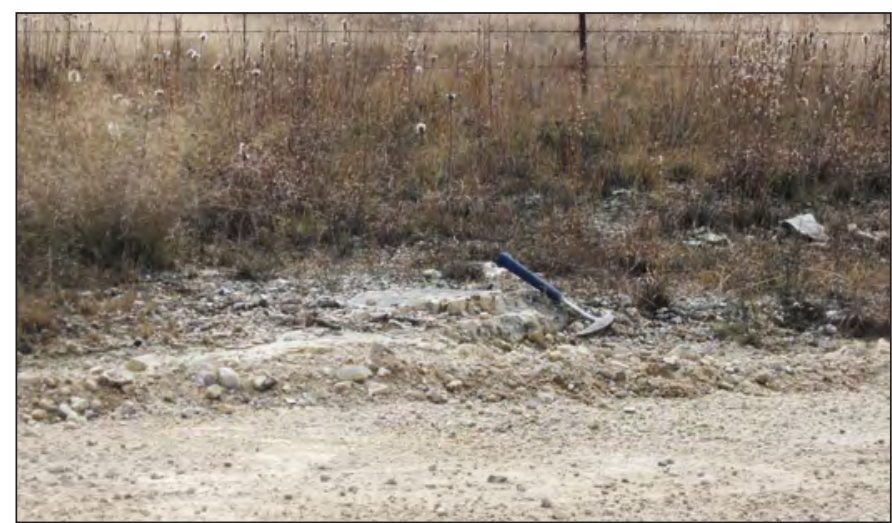

Figure 3. Typical road exposure of West Spring Creek Formation in northeast part of map area. In many localities, road grading exposes bedrock in road surfaces reflecting the shallow depth to bedrock and corresponding lack of surficial materials characteristic of much of the map area.

\section{Geologic Setting}

The geologic evolution of the map area and the Arbuckle Mountain region can be characterized by four phases that include (1) a rifting phase during Early and Middle Cambrian time, which was marked by the development of marginal faults and igneous activity; (2) a deposition and subsidence phase during Late Cambrian through Middle Mississippian time, when a thick sequence of shallow marine sediments accumulated along the continental margin, and a much thicker sequence of basin deposits accumulated in the subsiding basin; (3) an uplift and deformation phase during Pennsylvanian time, marked by intense folding and faulting; and (4) a phase of major erosion, which in combination with post-Pennsylvanian tilting and very minor faulting, resulted in southeast-trending streams and peneplanation of the Arbuckle Mountains (Christenson and others, 2011).

\section{Stratigraphy}

The Arbuckle Mountains consist of folded and faulted Precambrian and Cambrian igneous rocks and Paleozoic sedimentary rocks ranging in age from Cambrian through Late Pennsylvanian. These older deformed rocks are concealed along the east, north, and west flanks of the Arbuckle Mountains by flat to gently dipping Upper Pennsylvanian and Permian strata and concealed along the south flank by flat to gently dipping Lower Cretaceous rocks (fig. 4).

During the Cambrian, continental rifting occurred in the Ouachita orogenic belt in southern Oklahoma and during Late Cambrian through Middle Mississippian time thick successions of limestone and dolomite, along with some shale and sandstone, accumulated in the rift basin. During Late Mississippian and Pennsylvanian time, continental collision on the eastern and southern U.S. margins with Africa and South America, respectively, created the ancestral Arbuckle and Ouachita Mountains (fig. 1).
The rock units in the map area are all Paleozoic in age, with the exception of thin Quaternary alluvial and colluvial deposits exposed along the rivers and streams. Much of the map area is directly underlain by the upper part of the Arbuckle Group consisting of the Kindblade and overlying West Spring Creek Formations (figs. 4 and 5A, $B$ ). These Lower Ordovician rocks are the oldest Paleozoic rocks exposed in the quadrangle and are principally composed of dolomite; their extensive exposure in the Fittstown quadrangle represents part of the core of the Hunton anticline (fig. 4). Paleozoic rock units younger than the Arbuckle Group are exposed in the northeastern and southeastern parts of the quadrangle. Exposures of these younger Paleozoic units (Middle Ordovician to Pennsylvanian in age) form the moderately steep dipping northeastern flank of the Hunton anticline (northeast part of map area) and the gently southeastplunging nose of this anticline (southeastern corner of map area). Along this flank and the nose of the anticline, limestone, sandstone, and shale of the Middle Ordovician Simpson Group directly overlie older, upper Arbuckle Group units (fig. 6A, $B)$. In the northeastern part of the quadrangle and elsewhere in the Arbuckle Mountains, the Simpson Group is overlain by a sequence of Middle Ordovician to Pennsylvanian formations consisting of varying amounts of limestone, shale, marl, and minor sandstone.

Rock units older than those exposed in the Fittstown quadrangle are exposed south of the map area (fig. 4). These older units include the middle and lower parts of the Arbuckle Group and relatively thin exposures of the Cambrian-age Timbered Hills Group (Reagan Sandstone and overlying Honey Creek Formation) that unconformably overlie Proterozoic-age granitic basement rocks (fig. 4). The Timbered Hills Group and the overlying Arbuckle and Simpson Groups form the hydrostratigraphic units of the Arbuckle-Simpson aquifer (Faith and others, 2010), which is largely a carbonate aquifer that underlies much of the map area, and most of the central to eastern parts of the Arbuckle Mountain region (fig. 7A, $B$ ).

\section{Regional Structure}

The principal structural features in the Arbuckle Mountains are northwest-southeast oriented faults and folds (fig. 4). These major faults and folds are Pennsylvanian in age and formed from orogenic events along the southern margin of North America (Ham, 1973; Cardott and Chaplin, 1993). The most widely accepted interpretation of these structures is that the northwest-southeast trending folds developed from secondary northeast-southwest directed compression (transpression) related to primary left-lateral strike-slip along the major northwest-southeast striking faults (Tanner, 1963; Wickham, 1978; Marshak and others, 2003). Alternative interpretations indicate these structures formed primarily from northeastsouthwest directed compression associated with reverse offsets along the major northwest-southeast striking faults (for example, Brown, 1984; Naruk, 1994). 

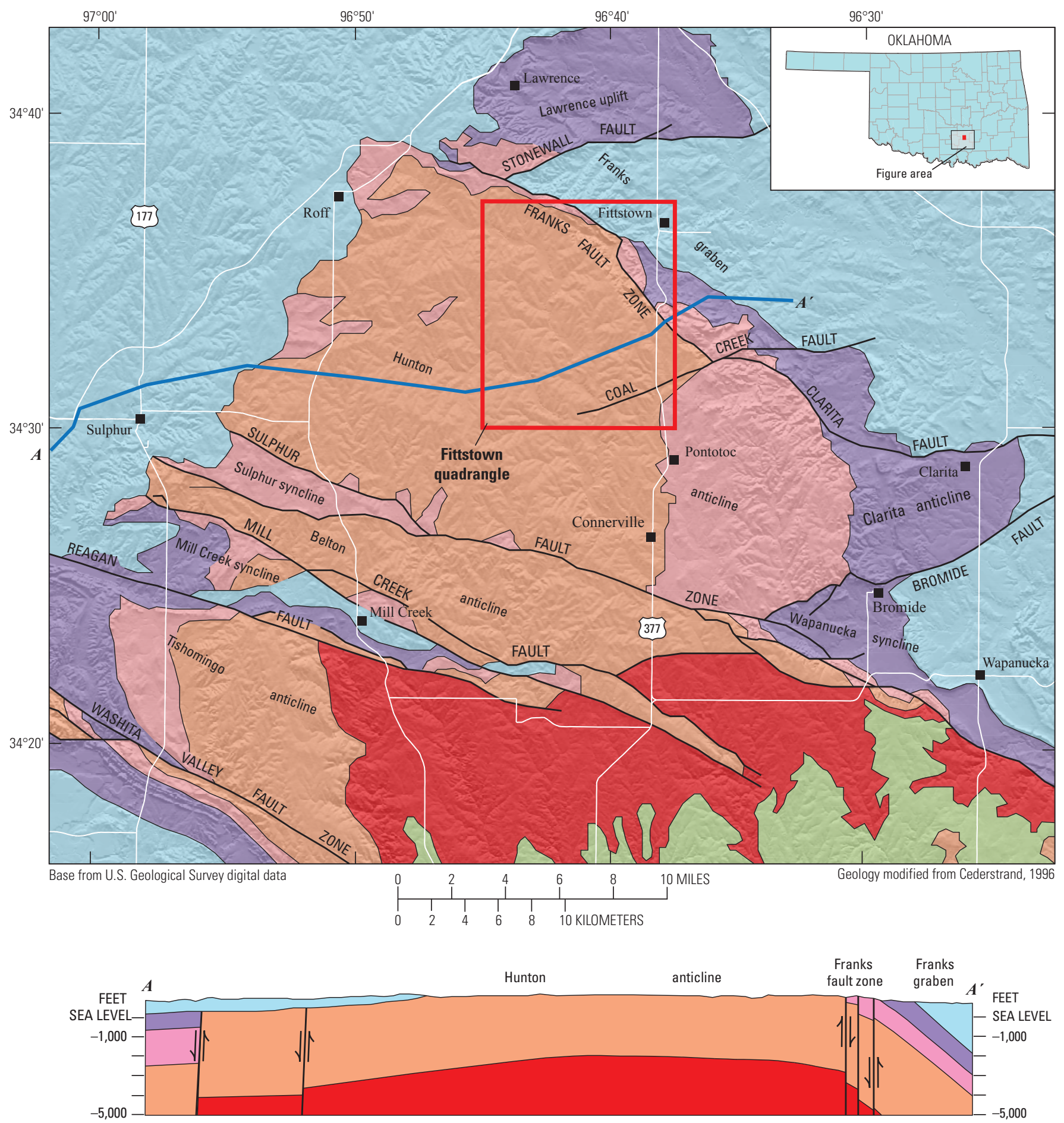

VERTICAL EXAGGERATION X5

\section{EXPLANATION}

\begin{tabular}{|l|l}
\hline & Cretaceous units \\
\hline \hline & Permian and Pennsylvanian units \\
\hline \hline & Mississippian-Middle Ordovician units
\end{tabular}
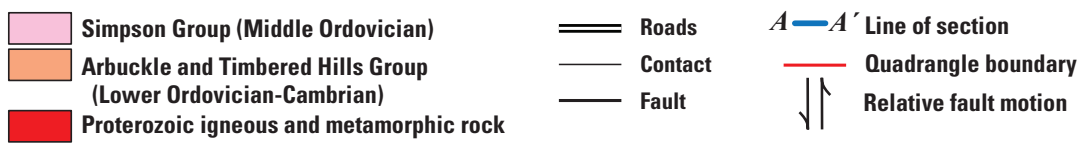

Figure 4. Generalized geologic sketch map and cross section of the northeastern Arbuckle Mountains, Oklahoma, including outline of the Fittstown 7.5' quadrangle map area (in red). Modified from Christenson and others (their fig. 7, 2011) with geology based on Cederstrand (1996). 

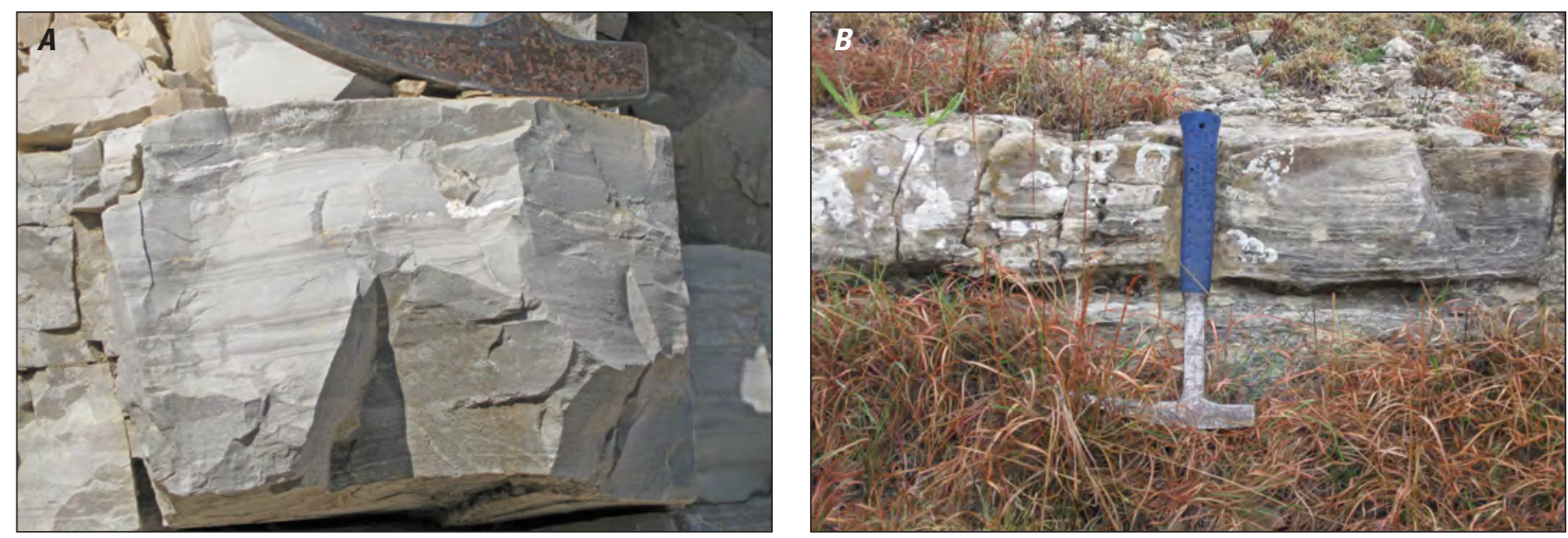

Figure 5. A, Greenish-gray, fine-grained to micritic dolomite of the West Spring Creek Formation showing laminations that are common in this rock unit. $B$, Light-tan to pale-green, tabular, thin bedded and laminated dolomite of the West Spring Creek Formation (Arbuckle Group) about 1.5 mi east of south-central part of eastern map border.
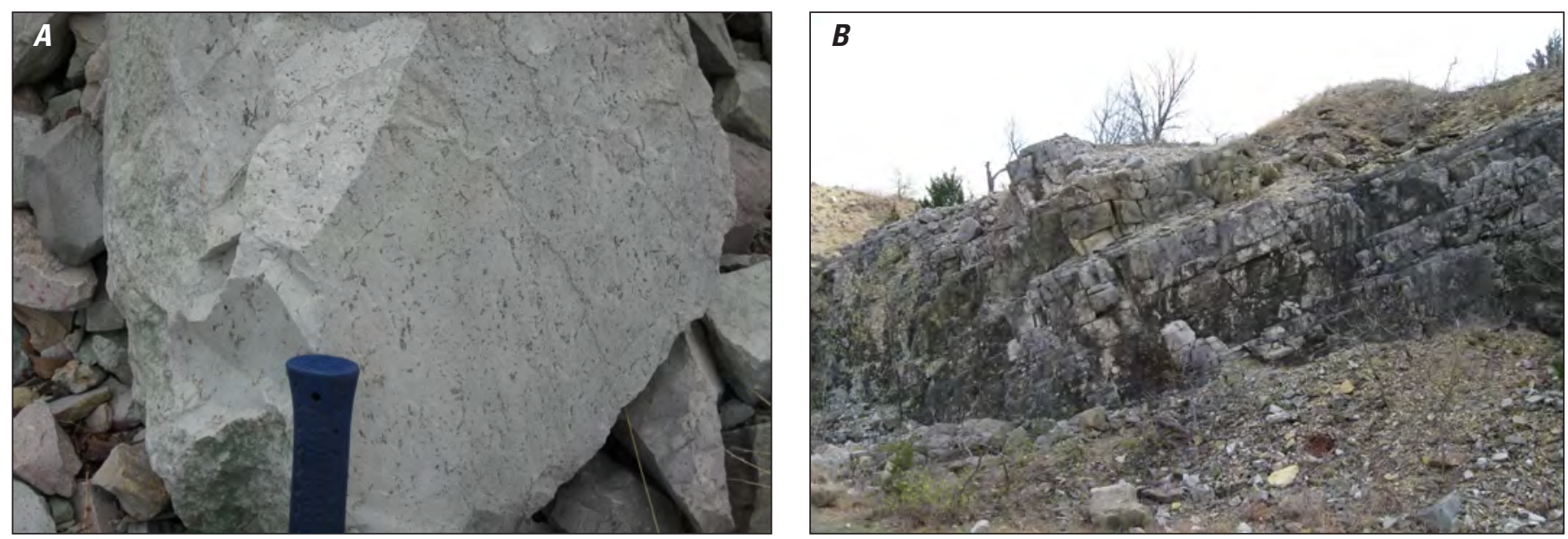

Figure 6. A, "Birdseye" limestone of the McLish Formation (Simpson Group) showing irregular flecks and masses of clear calcite in white to light-gray micritic limestone. B, Blocky-bedded "birdseye" limestone in quarry wall near central part of eastern map border.
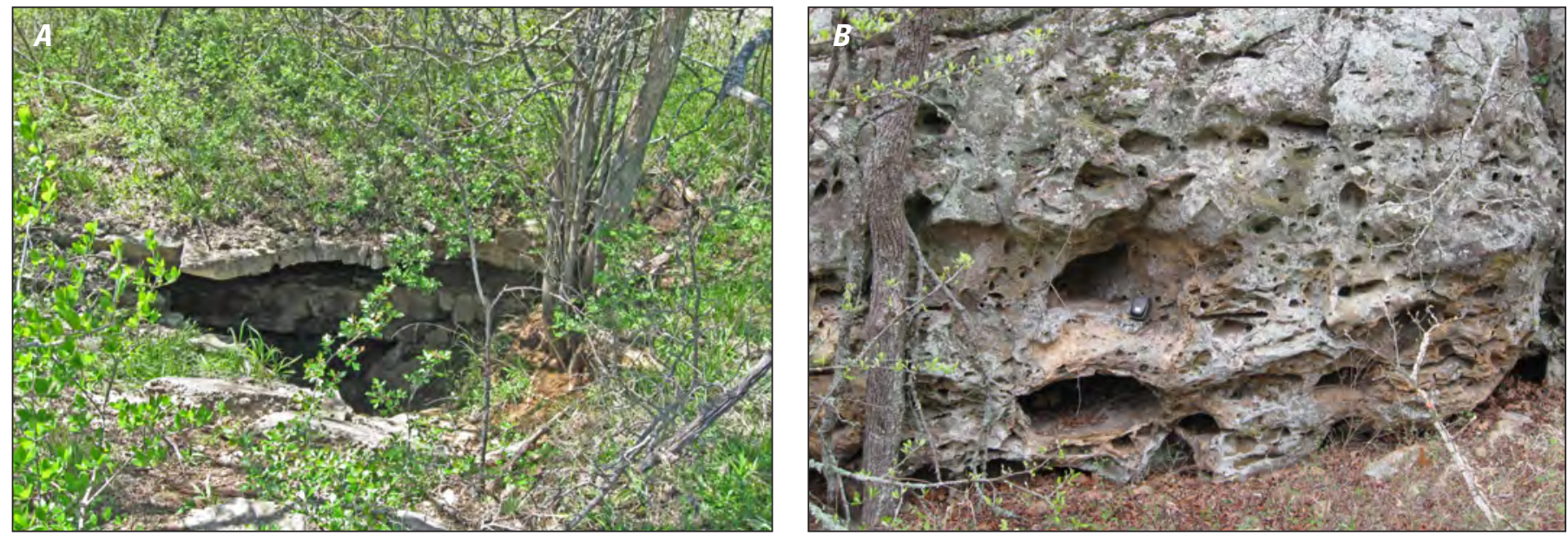

Figure 7. A, Solution cavity in the undifferentiated map unit consisting of the Bromide and McLish Formations (Obm) about 1 mi east of southern part of eastern map border. Surface opening of cavity is about 5-6 $\mathrm{m}$ in diameter. B, Solution cavities (vugs) in basal sandstone member of Oil Creek Formation (Simpson Group) about 1 mi east of south-central part of eastern map border. Rectangular, gray camera case between the two largest cavities is about $10 \mathrm{~cm}$ in length. 


\section{Structural Features in the Fittstown Quadrangle}

As in other parts of the Arbuckle Mountains, the principal structural features in the Fittstown quadrangle area are northwest-southeast oriented folds and faults. The Fittstown quadrangle includes parts of the northwest-southeast oriented Hunton anticline and the Franks fault zone that coincides with the northeastern flank of the Hunton anticline (map sheet and fig. 4). The map area also includes other northwest-southeast striking faults and some northeast-southwest and northerly striking faults that may be subsidiary to the more prominent northwest-southeast striking faults. The northeastern corner of the map area includes a small part of the Franks graben whose southwestern margin appears to be controlled by the northeastern flank of the Hunton anticline and the Franks fault zone (fig. 4). Cross section $A-A^{\prime}$ (fig. 4) transects the Fittstown quadrangle and the larger region of the northeastern Arbuckle Mountains; it provides a regional view of major structures in the map area.

As illustrated in cross section $A-A^{\prime}$ (fig. 4), the Hunton anticline is a very broad, asymmetric anticline that has a subhorizontal core, a very gently dipping southwestern limb, and a moderately steep dipping northeastern limb. In cross section view, the more steeply dipping northeastern limb and the subhorizontal to gentle dips of the remainder of this fold give it more the appearance of a monocline rather than an anticline (cross section $A-A^{\prime}$, fig. 4). The orientations of bedding appear somewhat chaotic in the part of the Hunton anticline core within the map area, but they are mostly consistent in having horizontal to gentle dips (commonly $<15^{\circ}$, see map sheet). The core of the Hunton anticline is faulted and fractured and includes numerous small faults that were not mapped (fig. 8). Faults and perhaps unidentified folds in this poorly exposed region may be responsible for the apparent chaotic bedding orientations. The chaotic bedding orientations also make the location of the Hunton anticline axis obscure; regional

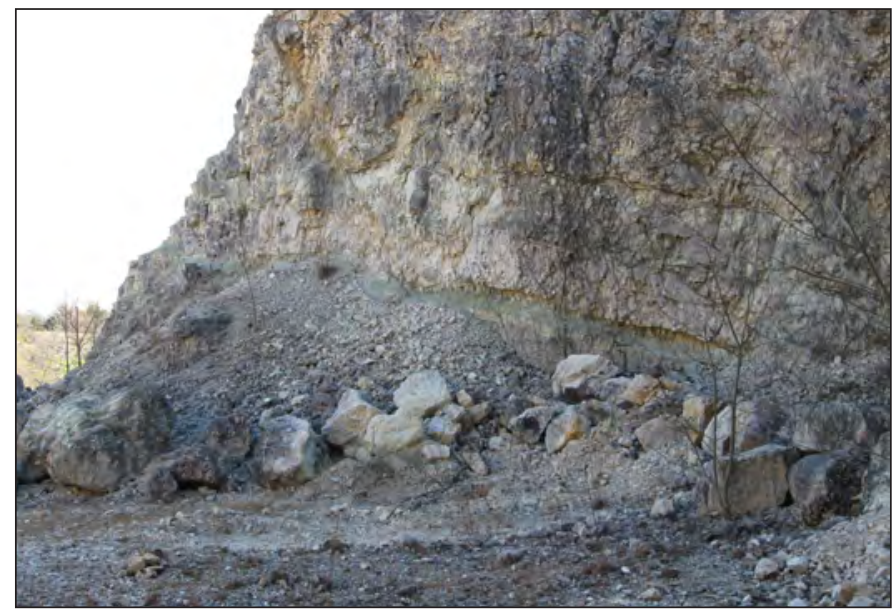

Figure 8. Highly fractured West Spring Creek Formation along quarry wall in east-central part of map area. Fractured zones appear to be associated with the mapped faults and with small, unmapped faults. relations shown in the sketch map (fig. 4) suggest that the axis might be inferred to cross the southwest corner of the map area, but such an inference is not depicted on the map.

Steeply dipping, northwest-southeast striking faults of the Franks fault zone cut and offset the moderately steep dipping rock units of the northeastern limb of the Hunton anticline. Other northwest-southeast striking faults as well as some northeast-southwest and northerly striking faults cut and offset rocks west of the Franks fault zone in the core of the Hunton anticline. Faults in the map area and elsewhere in the Arbuckle Mountains are generally poorly exposed and poorly expressed in the topography; however, apparent offsets of rock units across northwest-southeast striking faults, including the Franks fault zone, suggest mostly down to the northeast displacement. The Franks fault zone contains a northeast-trending syncline that disrupts the overall northeast dip of beds in the northeastern limb of the Hunton anticline (see map sheet). The syncline is bound between two prominent northwest-southeast striking faults and suggests a possible component of lateral slip along these faults. The curvature of contacts in other faults blocks of this zone, as is shown on the map, might suggest the presence of other synclinal and perhaps anticlinal features, but these are too speculative to depict on the map. The northeast-southwest and northerly striking faults commonly terminate against, and appear subsidiary to, the northwest-southeast striking faults.

The northeastern corner of the map area includes a small part of the Franks graben that is underlain by Middle and Upper Pennsylvanian units, the youngest rocks exposed in the map area (fig. 9). The Franks graben is topographically expressed as lowlands relative to adjacent highlands that border it to the southwest. In the map area, both the northeastern flank of the Hunton anticline and the Franks fault zone appear to collectively form and mark the southwestern margin of the graben (map sheet and fig. 4). Northeast of the map area, the Franks graben lacks distinct topographic expression and the northeasterly striking Stonewall fault separates the Lawrence uplift consisting of older rocks from younger

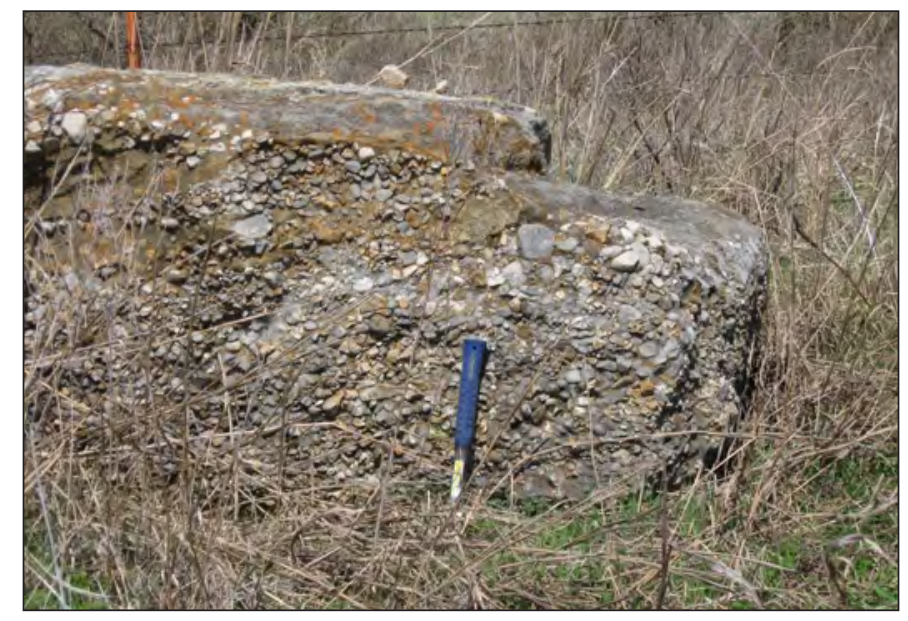

Figure 9. Limestone conglomerate that is common in Desmoinesian rocks in the northeast part of the map area. 
rocks in the graben south of the uplift (fig. 4). Just north of the map area, the Stonewall fault intersects and terminates at the Franks fault zone. The Stonewall fault and the Franks fault zone define northern and southwestern border faults of the graben, respectively. Eastern and southern borders or bordering faults of the graben, are either obscure or do not exist (fig. 4). The Franks fault zone and Stonewall fault cut Middle and Late Pennsylvanian rock units in the map area and nearby. North of the map area, however, the Franks fault zone terminates and appears to be covered by relatively younger Upper Pennsylvanian rock units (Ham and others, 1954). These relations suggest that these graben-border faults and the graben are Late Pennsylvanian in age and perhaps formed during latter stages of the Middle-Late Pennsylvanian orogenic events that deformed and uplifted this region.

\section{Acknowledgments}

The authors thank numerous landowners in Pontotoc and Johnston Counties that graciously granted permission to access their land. Ric Page (USGS) and Marieke Dechesne (USGS) provided thorough and helpful technical reviews. Paco Van Sistine (USGS) provided the review of the metadata and helped revise and standardize the Geographic Information System digital data for the geologic map. The digital topographic base was prepared by Theodore R. Brandt. Julie Herrick (USGS) was responsible for the geologic names review, final editing and layout of the map sheet and pamphlet, and for many aspects of the final figures shown in the pamphlet and on the map sheet. 


\section{Description of Map Units}

Stratigraphic nomenclature and descriptions of the Paleozoic rocks exposed in the map area are from Morgan (1924), Ham and others (1954), Ham (1973), Hart (1974), Fay (1989), Johnson (1990), Blome and others (2013), the USGS National Geologic Map Database GEOLEX (http://ngmdb.usgs.gov/Geolex/geolex.html), and the authors' field observations from 2009 through 2011. The map unit descriptions below include the general lithologies, thickness, fossil groups, and their provincial series according to the guidelines of the U.S. Geological Survey Geologic Names Committee (2009, 2010). Geologic provincial series names used are from the geologic time scale of Gradstein and others (2004) and Walker and Geissman (2009).

\section{Quaternary Stratigraphy}

Qac Alluvium and colluvium, undifferentiated (Quaternary) — Unconsolidated sand, silt, clay, and gravel along rivers and streams that are inundated regularly; includes some terrace deposits and small alluvial fan and colluvial deposits along the flanks of major valleys. Locally includes small exposures of underlying bedrock. Thickness varies; ranges from about 3 to $15 \mathrm{ft}$ ( 1 to $5 \mathrm{~m}$ )

\section{Paleozoic Stratigraphy}

Pm Missourian Series formations, undifferentiated (Upper Pennsylvanian, Missourian)—Typical lithologies include fine- to coarse-grained light-brown, sandstone; gray to bluish-gray shale; chert conglomerate; limestone conglomerate; and sparse, thin beds of white to light-gray limestone. Exposed in northeastern part of map area, along the north-eastern limb of the Hunton anticline. Only the lowermost formations of the Missourian Series are preserved in map area, the Francis Formation and the Seminole Formation (Ham, 1954; Hart, 1974); these units are poorly exposed and mapped as a single undifferentiated map unit $(\mathrm{Pm})$ in the Fittstown quadrangle. Fossils include crinoids, endothyrids, bryozoans, brachiopods, and mollusks. Missourian Series formations are the youngest Paleozoic rocks exposed in map area and they disconformably overlie Desmoinesian Series formations described below. Maximum thickness of about 2,800 ft $(853 \mathrm{~m})$ in areas nearby, but only about $200 \mathrm{ft}$ $(60 \mathrm{~m})$ of lower part of the Missourian Series is preserved in the quadrangle

Pdm Desmoinesian Series formations, undifferentiated (Middle Pennsylvanian, Desmoinesian) — Typical lithologies include fine- to coarse-grained, gray and light-brown sandstone; bluish-gray and brown shale; limestone conglomerate; chert conglomerate; and sparse, thin beds of fossiliferous, light-gray to white limestone (fig. 9). Exposed in the northeastern part of map area, along the northeastern limb of the Hunton anticline. In the Fittstown quadrangle, the Desmoinesian Series map unit comprises five formations including (from top to base) the Holdenville, Wewoka, Boggy, Savanna, and McAlester Formations (Ham, 1954; Hart, 1974). These Desmoinesian Series formations contain similar lithologies, are uniformly poorly exposed, and were mapped as a single undifferentiated map unit in the quadrangle. Fossils include crinoids, endothyrids, brachiopods, and mollusks. Unconformably overlies the Springer Group (PMs), Caney Shale (Mc), and undifferentiated Mississippian-Devonian rock units (MDsw) near the eastern border of the map area. Maximum thickness of more than $6,000 \mathrm{ft}(1,830 \mathrm{~m})$ in nearby areas, but only about 3,000 $\mathrm{ft}(915 \mathrm{~m})$ thick in the map area

PMs Springer Group (Lower Pennsylvanian to Upper Mississippian, Morrowan to Chesterian) - Dark-gray to bluish-gray, fissile shale and thin beds and lenses of sandstone and limestone. Contains ferruginous carbonate concretions. Sandstone beds more abundant in upper part. Includes Goddard Shale and includes Union Valley Sandstone and equivalents at its base. Overlies Caney Shale (Mc) near eastern border of map area. Springer Group is best exposed in the Criner Hills of Carter County, Okla., southwest of the map area near and southwest of Ardmore, Okla. Fossils include various species of brachiopods, bryozoans, and bivalves. Top is truncated by gentle, angular unconformity at base of overlying Desmoinesian Series unit ( $\mathbb{P d m})$; maximum thickness about $350 \mathrm{ft}(107 \mathrm{~m})$ in map area 
Mc Caney Shale (Upper to Middle Mississippian, Chesterian to Meramecian)—Dark-gray to black, laminated, fissile and friable shale containing septarian and phosphatic concretions. Because the shale is friable, individual outcrops are rarely observed; usually expressed as lush, grassy fields and slopes. Concretions vary in size, up to $3 \mathrm{ft}(1 \mathrm{~m})$ or more in diameter. Fossils include conodonts, pelecypods, gastropods, ostracodes, goniatites, and cephalopods. Overlies Welden Limestone (upper part of MDw) near eastern border of map area. Top is truncated by gentle, angular unconformity at base of overlying Desmoinesian Series unit (Pdm); maximum thickness about $350 \mathrm{ft}(107 \mathrm{~m})$ in map area

MDw

Welden Limestone and Woodford Shale, undifferentiated (Lower Mississippian, Kinderhookian to Devonian) - Undifferentiated map unit that includes the very thin Welden Limestone and the much thicker underlying Woodford Shale. Southwest of map area, in the central and southern Arbuckle Mountains, Sycamore Limestone (Lower Mississippian) overlies the Welden Limestone. However, Sycamore Limestone is absent in the map area and throughout most of Hunton anticline region (northeastern Arbuckle Mountains) as a result of an unconformity at the base of the Caney Shale (Ham, 1973). This undifferentiated map unit (MDw) is exposed in northeastern part of map area where basal beds of Woodford Shale overlie limestone and marlstone of the Hunton Group. The Welden Limestone and Woodford Shale are described separately below

Welden Limestone (Lower Mississippian, Kinderhookian) - Consists of light-gray to bluish-gray, crystalline, argillaceous, fossiliferous limestone, which weathers to a yellow or orange color; commonly sandy near base. This thin limestone contains scattered phosphate nodules similar to those in upper part of the Woodford Shale. Thickness ranges from 0 to $5 \mathrm{ft}(0$ to $2 \mathrm{~m})$; average thickness $2 \mathrm{ft}(0.7 \mathrm{~m})$

Woodford Shale (Lower Mississippian, Kinderhookian to Upper Devonian) - Light- to dark-gray, fissile shale, siliceous shale, bedded chert, and black, fissile bituminous shale. Locally, siliceous shale and bedded chert make up most of formation. Chert and phosphatic concretions occur in upper part of unit. Thickness varies from 200 to $550 \mathrm{ft}$ (61 to $168 \mathrm{~m}$ ); increases in thickness to the south in Arbuckle Mountains. Total thickness estimated to be about 250-300 ft (76-91 m) in map area

Hunton Group, undifferentiated (Lower Devonian to Upper Ordovician, Cincinnatian)-Undifferentiated map unit consisting mostly of limestone, marlstone, and shale. At the base of the unit are white, silicified, oolitic limestone beds. Above the oolitic limestone are blueish- and beige-colored limestone and marlstone. Middle part of unit is predominantly yellow- to tan-weathering shale and mudstone with thin marlstone interbeds. Upper $50 \mathrm{ft}(15 \mathrm{~m})$ of unit contains thin-bedded, fossiliferous marlstone and white or light-gray, granular to crystalline limestone. Some marlstone is composed mainly of shell fragments, and chert beds and nodules are common near top of Hunton Group. Total thickness of the Hunton Group varies greatly throughout the Arbuckle Mountains and ranges from about $100 \mathrm{ft}(30 \mathrm{~m})$ to as much as $600 \mathrm{ft}(183 \mathrm{~m})$. In the Fittstown quadrangle, the Hunton Group is estimated to be 275-300 ft (84-91 m) in total thickness. Where exposed in the east-central part of the map area, the basal oolitic limestone overlies Sylvan Shale; where exposed in the north-central part of the map area, this undifferentiated unit is everywhere bounded by faults along the northeastern flank of the Hunton anticline. This undifferentiated map unit (Hunton Group) includes as many as seven, thin (locally absent) formations that consist predominantly of varying amounts of limestone, marlstone, and interbedded shale. In descending stratigraphic order, these seven formations are: the Frisco, Bois d'Arc, Haragan, Henryhouse, Clarita, Cochrane, and Keel Formations (Johnson, 1990). Throughout the map area and regions nearby, poor exposures and the thin character of these formations require that they be mapped combined as a single undifferentiated unit unit that has shaley upper part (Sylvan Shale) and thicker, limestone-rich lower part (Viola Group). Basal limestone of the Viola Group overlies limestone and interbedded shale of the upper Simpson Group (Obm) in the east-central and northeastern parts of the map area. Throughout the map area and regions nearby, poor exposures require that the Sylvan Shale and Viola Group be mapped combined as a single undifferentiated unit. Total thickness of this undifferentiated map unit is as much as 1,000 ft (305 m) in the Arbuckle Mountain region and is estimated to be about $650 \mathrm{ft}(190 \mathrm{~m})$ in map area. The Sylvan Shale and Viola Group are described separately below 
Sylvan Shale - Principally poorly exposed, green to gray or tan, fissile, calcareous and dolomitic shale. Commonly forms swales or subtle rolling hills between resistant underlying and overlying limestone units; locally is silty or siliceous; contains graptolites and chitinozoans (Decker, 1936). Thickness ranges from 50 to $325 \mathrm{ft}$ ( 15 to $99 \mathrm{~m}$ ) in the Arbuckle Mountains region and is estimated to be about $100 \mathrm{ft}(30 \mathrm{~m})$ thick in map area

Viola Group - Composed of limestones of the Welling and Viola Springs Formations (Ham and others, 1954). Welling Formation is gray, coarse-grained, fossiliferous limestone. The Viola Springs Formation is white to bluish-gray, fine- to medium-grained, locally very fossiliferous limestone with thin interbeds of green to gray, fissile shale; limestone locally contains chert nodules in lower and middle parts. Thickness ranges from about 350 to $900 \mathrm{ft}$ ( 107 to $168 \mathrm{~m}$ ) in the Arbuckle Mountains region and is estimated to be about $550 \mathrm{ft}$ $(168 \mathrm{~m})$ thick in map area

Simpson Group (Middle Ordovician) - Composed mainly of sandstone and fossiliferous limestone with interbedded shale and marlstone. Pale-brown to white sandstone beds occur throughout the Simpson Group and thicker sandstone units, ranging up to about $400 \mathrm{ft}(122 \mathrm{~m})$ thick, typically form basal units of individual Simpson Group formations. In the map area, the Oil Creek Formation has the thickest basal sandstone unit and it is about $200 \mathrm{ft}(61 \mathrm{~m})$ thick. Thin to thick beds of pale-gray to white limestone and dolomitic limestone and yellowish-weathering marlstone are commonly interbedded with thin pale- green, marly shale layers. Simpson Group includes as many as five formations, which include (from top to base) the Bromide, Tulip Creek, McLish, Oil Creek, and Joins Formations (Decker and Merritt, 1931). The Tulip Creek and Joins Formations are not present in Fittstown quadrangle or elsewhere in the Hunton anticline region. In the Fittstown quadrangle, the Bromide and McLish Formations are combined (map unit Obm) and the Oil Creek Formation (Oo) is mapped separately. Basal Simpson Group strata of the Oil Creek Formation (Oo) overlie upper Arbuckle Group strata in the north-central and southeastern parts of the map area, and the Simpson Group is exposed in several fault blocks in the northeastern part of the map area. Regionally, the Simpson Group ranges in thickness from 1,000 to $2,300 \mathrm{ft}$ (305 to $700 \mathrm{~m}$ ) and is estimated to be about 1,150-1,250 ft (350-380 m) thick in map area

Bromide and McLish Formations, undifferentiated - Primarily thin to thick beds of alternating sandstone, shale, and limestone. These two formations and the intervening Tulip Creek Formation (absent in map area) compose the upper part of the Simpson Group that ranges regionally in thickness from about 750 to 1,400 ft ( 229 to $427 \mathrm{~m}$ ). In the map area, the total combined thickness of the Bromide and McLish Formations $(\mathrm{Obm})$ is estimated to be about 700-750 ft (213-229 m). The Bromide and McLish Formation are described separately below

Bromide Formation - Upper part of the undifferentiated Obm map unit. Mostly interbedded limestone and shale with basal quartzose sandstone. Limestone buff-colored, shale grayish-green, and sandstone brown to white. Limestone is commonly fossiliferous with brachiopods and ostracodes. Limestone and minor dolomite in the upper part of the unit are informally called the "upper Bromide limestone." Cooper (1956, p. 120-121) divided the Bromide Formation into two members, the Mountain Lake Member (lower) and the Poolville Member (upper). Thickness of the formation varies, from $315 \mathrm{ft}(96 \mathrm{~m})$ to over $600 \mathrm{ft}(183 \mathrm{~m})$, and is estimated to be about $350 \mathrm{ft}(107 \mathrm{~m})$ thick in map area The basal sandstone unit can vary greatly in thickness, from about $50(15 \mathrm{~m})$ to $300 \mathrm{ft}(91 \mathrm{~m})$ thick; its average thickness in map area is estimated to be about $100 \mathrm{ft}$ (31 m)

McLish Formation - Lower part of the undifferentiated Obm map unit. Mostly interbedded limestone and shale above a quartzose sandstone at the base of the unit; the basal sandstone thins from east to west in the Arbuckle Mountains. Some of the limestone is dense with small blebs of calcite and it is informally termed "birdseye" limestone (fig. $6 A$ and $B$ ). The basal sandstone overlies limestone of the underlying Oil Creek Formation (Oo) in the map area. Maximum thickness is $450 \mathrm{ft}(137 \mathrm{~m})$ in the eastern parts of the Arbuckle Mountains and 400-500 ft (122-152 m) thick along the U.S. I-35 corridor (Fay, 1989); estimated to be about $350-400 \mathrm{ft}(107-122 \mathrm{~m})$ thick in the map area

Oil Creek Formation - Lower part and basal formation of Simpson Group in map area and adjacent areas of Hunton anticline region. Mostly gray to tan, granular limestone, greenish-gray shale, and pale-brown to white, fine- to medium-grained sandstone. Characteristically consists of basal sandstone overlain by limestone and shale. Upper part of unit contains some calcite-cemented sandstone. Although locally absent in parts of the Arbuckle Mountains, the basal Oil Creek sandstone is commonly the thickest sandstone (up to $400 \mathrm{ft}$ or $122 \mathrm{~m}$ thick) in the Simpson Group and is locally petroliferous (tar sand was mined in some localities in the Arbuckle Mountains) and, in places, is argillaceous or calcareous. The basal sandstone is 
estimated to be about $200 \mathrm{ft}(61 \mathrm{~m})$ thick in the map area. The Oil Creek Formation is estimated to be about $450-500 \mathrm{ft}(137-152 \mathrm{~m})$ thick in the north-central part of the map area where the entire formation is exposed underlying the undifferentiated, upper Simpson Group unit $(\mathrm{Obm})$ and overlying the West Spring Creek Formation (Ow) of the Arbuckle Group. The Oil Creek Formation is also exposed in fault blocks in the northeastern part of the map area

Arbuckle Group, upper part (Lower Ordovician) - The Arbuckle Group (Lower Orodovician-Upper Cambrian) includes up to $6,700 \mathrm{ft}$ (2,042 m) of thin- to massive-bedded limestone and dolomite, with some sandstone and shale, locally subdivided into eight formations (Fay, 1989), including (from top to base) the West Spring Creek, Kindblade, Cool Creek, and McKenzie Hill Formations, Butterly Dolomite, Signal Mountain Formation, Royer Dolomite, and Fort Sill Limestone. Only the West Spring Creek and Kindblade Formations, which compose the upper part of the Arbuckle Group, are exposed in the map area and are described separately below

West Spring Creek Formation (Lower Ordovician) - Pale-green to tan, fine-grained, thin-bedded and laminated dolomite, some pale-gray to green shale, and sparse sandstone beds near top of formation (fig. $5 A$ and $B$ ). Isolated, well-rounded sand grains are relatively common in dolomite, particularly in upper part of formation. Unit is 1,515 ft (462 m) thick along the U.S. I-35 corridor (Fay, 1989) in southwestern Arbuckle Mountains and is estimated to be a minimum of about $1,000 \mathrm{ft}(305 \mathrm{~m})$ thick in map area. Overlies Kindblade Formation in southwestern part of map area; similar appearance and lithologies of West Spring Creek and Kindblade make contact difficult to discern

Kindblade Formation (Lower Ordovician) - Predominantly pale-green to tan, fine-grained, thick-bedded dolomite and minor pale-gray to -green shale. Unit is very similar in appearance and lithology to the West Spring Creek Formation (Ow). The Kindblade is typically thick-bedded and lacks laminations, whereas the West Spring Creek is typically thin-bedded and laminated. Unit is $1,410 \mathrm{ft}(430 \mathrm{~m})$ thick along the U.S. I-35 corridor (Fay, 1989) in the southwestern Arbuckle Mountains and generally thins to the north and east. The base of the Kindblade Formation is not exposed in the map area; minimum exposed thickness in map area is estimated to be about $800 \mathrm{ft}(244 \mathrm{~m})$ 


\section{References Cited}

Blome, C.D., Lidke, D.J., Wahl, R.R., and Golab, J.A., 2013, Geologic map of Chickasaw National Recreation Area, Murray County, Oklahoma: U.S. Geological Survey Scientific Investigations Map 3258, 28 p., 1 sheet, scale 1:24,000, http://pubs.usgs.gov/sim/3258/.

Brown, W.G., 1984, Washita Valley fault system-A new look at an old fault, in Borger, J.G. II, ed., Technical Proceedings of the 1981 American Association of Petroleum Geologists mid-continent regional meeting: Oklahoma City Geological Society, p. 68-80.

Cardott, B.J., and Chaplin, J.R., 1993, Guidebook for selected stops in the western Arbuckle Mountains, Southern Oklahoma: Oklahoma Geological Survey Special Publication 93-3, 55 p.

Cederstrand, J.R., 1996, Digital geologic map of ArdmoreSherman quadrangles, south-central Oklahoma: U.S. Geological Survey Open-File Report 96-370, scale 1:250,000, http://ok.water.usgs.gov/gis/geology.

Christenson, Scott, Osborn, N.I., Neel, C.R., Faith, J.R., Blome, C.D., Puckette, James, and Pantea, M.P., 2011, Hydrogeology and simulation of groundwater flow in the Arbuckle-Simpson Aquifer, south-central Oklahoma: U.S. Geological Survey Scientific Investigations Report 2011-5029, 104 p.

Cooper, C.L., 1931, Map of the Arbuckle Mountains: Oklahoma Geological Survey Bulletin 55, pl. 1.

Cooper, G.A., 1956, Chazyan and related brachiopods: Smithsonian Miscellaneous Collections, v. 127, part 1, 1,245 p.

Decker, C.E., 1936, Some tentative correlations on the basis of graptolites of Oklahoma and Arkansas: American Association of Petroleum Geologists Bulletin, v. 20, no. 3, p. 301-311.

Decker, C.E., and Merritt, C.A., 1931, The stratigraphy and physical characteristics of the Simpson group: Oklahoma Geological Survey Bulletin, no. 55, 112 p.

Elias, M.K., and Branson, C.C., 1959, Type section of the Caney Shale: Oklahoma Geological Survey Circular, no. 52, $24 \mathrm{p}$.

Fairchild, R.W., Hanson, R.L., Davis, R.E., 1990, Hydrology of the Arbuckle Mountains area, south-central Oklahoma: Oklahoma Geological Survey, Circular 91, 112 p., 2 map sheets, scale 1:100,000.
Faith, J.R., Blome, C.D., Pantea, M.P., Puckette, J.D., Halihan, Todd, Osborn, Noel, Christenson, Scott, Pack, Skip, 2010, Three-dimensional geologic model of the ArbuckleSimpson aquifer, south-central Oklahoma: U.S. Geological Survey Open-File Report 2010-1123, 29 p.

Fay, R.O., 1989, Geology of the Arbuckle Mountains along Interstate 35, Carter and Murray Counties, Oklahoma: Oklahoma Geological Survey Guidebook 26, 50 p.

Gradstein, Felix, Ogg, James, and Smith, Alan, eds., 2004, A geologic time scale 2004: Cambridge, U.K., Cambridge University Press, 589 p.

Ham, W.E., 1955, Geology of the Arbuckle Mountain region: Oklahoma Geological Survey Guidebook 3, 61 p.

Ham, W.E., 1973, Regional Geology of the Arbuckle Mountains, Oklahoma: Oklahoma Geological Survey Special Publication 73-3, $61 \mathrm{p}$.

Ham, W.E, McKinley, M.E., and others, 1954, Geologic map and sections of the Arbuckle Mountains, Oklahoma: Oklahoma Geological Survey Map A-2, scale 1:72,000. [Superseded by Johnson, 1990, Oklahoma Geological Survey Geologic Map GM-31]

Hart, D.L., Jr., 1974, Reconnaissance of the water resources of the Ardmore and Sherman quadrangles, southern Oklahoma: Oklahoma Geological Survey, Hydrologic Atlas Map HA-3, 1:250,000 scale.

Heran, W.D., Green, G.N., and Stoeser, D.B., compilers, 2003, A digital geologic map database for the State of Oklahoma: U.S. Geological Survey Open-File Report 03-247, http://pubs.usgs.gov/of/2003/ofr-03-247/.

Johnson, K.S., 1990, revision of Ham, W.E., McKinley, M.E., and others, 1954, Geologic map and sections of the Arbuckle Mountains, Oklahoma: Oklahoma Geological Survey, Geologic Map GM-31, scale 1:100,000. [Supersedes Ham and others, 1954, Oklahoma Geological Survey Map A-2]

Marshak, Stephen, Nelson, W.J., and McBride, J.H., 2003, Phanerozoic strike-slip faulting in the continental interior platform of the United States-Examples from the Laramide orogen, Midcontinent, and Ancestral Rocky Mountains: Geological Society of London, Special Publications 2003, v. 210, p. 159-184.

Morgan, G.D., 1924, Geology of the Stonewall quadrangle, Oklahoma: Oklahoma Bureau of Geology Bulletin, no. 2, $248 \mathrm{p}$. 
Naruk, S.J., 1994, Geometric analyses and balanced cross sections of the Arbuckle Mountains and Washita Valley fault: Oklahoma City Geological Society, Shale Shaker, v. 45 , p. $158-162$.

Stoeser, D.B., Green, G.N., Morath, L.C., Heran, W.D., Wilson, A.B., Moore, D.W., and Van Gosen, B.S., 2007, Preliminary integrated geologic map databases for the United States: Central States: U.S. Geological Survey Open-File Report 2005-1351, v. 1.2, http://pubs.usgs.gov/of/2005/1351/. (Revised December 2007)

Taff, J.A., 1903, Description of the Tishomingo quadrangle (Indian Territory): U.S. Geological Survey Geologic Atlas of the United States, Tishomingo Folio, no. 98, 8 p.

Taff, J.A., 1904, Preliminary report on the geology of the Arbuckle and Wichita Mountains in Indian Territory and Oklahoma, with an appendix on Reported ore deposits of the Wichita Mountains, by H. Foster Bain: U.S. Geological Survey Professional Paper 31, 97 p.

Tanner, W.F., 1963, Tectonic patterns in AppalachianOuachita-Oklahoma mountain complex: Oklahoma City Geological Society, Shale Shaker, v. 14, no. 3, p. 2-6.
Tomlinson, C.W., 1929, The Pennsylvanian System in the Ardmore basin: Oklahoma Geological Survey Bulletin, no. $46,79 \mathrm{p}$.

U.S. Geological Survey Geologic Names Committee, 2009, Divisions of geologic time-Major chronostratigraphic and geochronologic units: Stratigraphy, v. 6, no. 2, p. 90-92.

U.S. Geological Survey Geologic Names Committee, 2010, Divisions of geologic time-Major chronostratigraphic and geochronologic units: U.S. Geological Survey Fact Sheet 2010-3059, 2 p.

Walker, J.D., and Geissman, J.W., 2009, Commentary-2009 GSA Geologic Time Scale: Geological Society of America, GSA Today, p. 60-61.

Wickham, J.S., 1978, The southern Oklahoma Aulacogen, in Denison, R.E., and Wickham, J.S., eds., Structural style of the Arbuckle region, Geological Society of America Guidebook, South Central Section, Field Trip no. 3, March 8-9, 1978: Geological Society of America Guidebook, p. 9-41. 
Publishing support provided by:

Denver Publishing Service Center, Denver, Colorado

For more information concerning this publication, contact:

Center Director, USGS Geosciences and Environmental Change Science Center

Box 25046, Mail Stop 980

Denver, C0 80225

(303) 236-5344

Or visit the Geosciences and Environmental Change Science Center Web site at: http://gec.cr.usgs.gov/

This publication is available online at: https://doi.org/10.3133/sim3371 


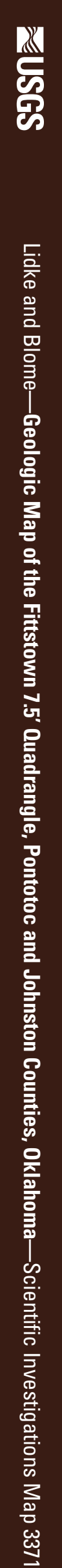

ISSN 2329-132X (online 